\title{
Concomitant testicular infection by Zika virus and Schistosoma mansoni in a Brazilian young boy
}

\author{
Leonardo Souza Alves ${ }^{1 *}$, Cesar Estanislau ${ }^{2}$, Lucio Barreto ${ }^{3}$, Francisco Batista ${ }^{3}$, Nivaldo Toppa ${ }^{4}$ \\ ${ }^{1} \mathrm{MD}$, Urologist. Sociedade Brasileira de Urologia. American Urologic Association. Procriar - Instituto de Urologia e Andrologia, Belo Horizonte, MG, Brazil \\ ${ }^{2}$ Biologist. Departament of Biologic Sciences, Faculdade Newton de Paiva, Belo Horizonte, MG, Brazil \\ ${ }^{3} \mathrm{MD}$, Faculdade Ciências Médicas de Minas Gerais (FCM-MG), Belo Horizonte, MG, Brazil \\ 4Patologist. Ex-Professor of Pathology, UFMG, Belo Horizonte, MG, Brazil
}

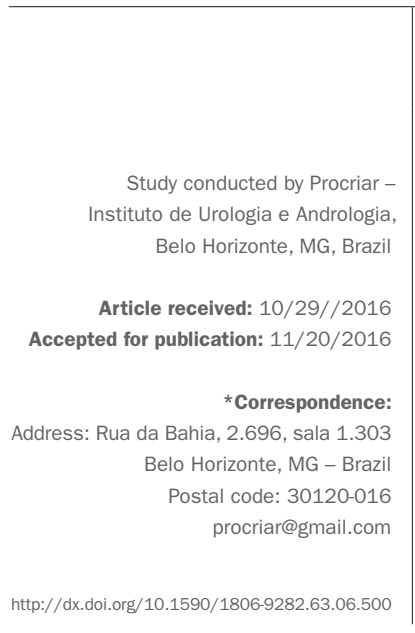

\section{Case}

We report the case of a young Brazilian boy, who was referred with inflammation of the right testicle and epididymis. The patient presented with volumetric expansion but no pain, without any apparent cause. Scrotal trauma or unprotected sexual activity were not reported. The preliminary scans, magnetic resonance imaging (MRI) and duplex scan determinated a possible testicular cancer. Analysis of spermogram showed the presence of immobile and dead sperm. The analysis of sperm culture showed no infection. Laboratory exams included: Alpha-fetoprotein (AFP) blood test, lactate dehydrogenase (LDH) and beta-human chorionic gonadotropin (hCG), all normal. The patient was prescribed the use of antibiotic and anti-inflammatory medication for 10 days, but no reduction in testicular mass size was observed. After talking to the patient about the diagnostic difficulties, we opted for orchiectomy.

Preoperative tests were all normal. The surgery was uneventful, and the patient was discharged on the same day. The examination of the surgical piece demonstrated extensive right testicular and epididymal fibrosis. The microscopic examination of the testis ruled out the possibility of cancer, but confirmed the diagnosis of extensive loss of testicular structure and schistosome egg-induced granulomas (Figure 1). After surgery, the patient's relatives reported that he had had contact with stagnant water approximately 60 days before the symptoms started. According to the family, the boy was admitted to the hospital with flu-like symptoms, low fever and rashes on chest and lower limbs. At the time of hospitalization, infection with Dengue virus was suspected. Symptomatic treatment was initiated with analgesics. The patient was hospitalized for 48 hours and then discharged. The blood test (RT-PCR) performed at the time of admission confirmed later that the etiology was a Zika virus infection. The patient was discharged with instructions for frequent hydration and no more. After surgery, the patient received oral treatment with oxamniquine to treat infection with Schistosoma, being instructed to only have sexual intercourse with the use of condoms for a period of 6 months.

\section{ZIKA VIRUS}

Zika virus (ZIKV) is an RNA virus of the Flaviviridae family, related to the Dengue and Yellow fever viruses. It causes Zika fever, a disease with symptoms similar to Dengue fever and Chikungunya, but more lenient (Figure 2).

The virus was first identified in 1947, in Uganda, in a rhesus monkey that was infected with yellow fever virus. The virus was unknown in humans up to that time, and the first report of it infecting humans was in 1954 in Nigeria. The dissemination occured in countries of Africa and Asia. ZIKV probable transmission route involved the 


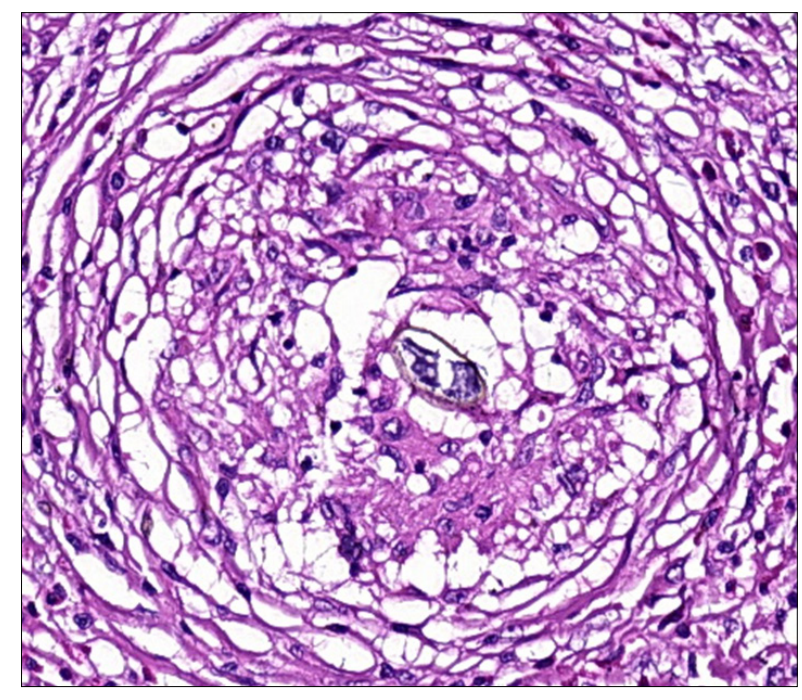

FIGURE 1 Granuloma in fibrosis phase with a viable S. mansoni egg in the middle. (Photo by Nivaldo H. Toppa).

2014 FIFA World Cup, also being carried by immigrants from Africa. ${ }^{2,3,8,11}$ Symptoms include: mild fever, pruritus and cutaneous rash, fatigue, myalgia, dehydration, diarrhea, photophobia, dizziness and loss of appetite. These symptoms may remain for 7 to 30 days. Unlike the Dengue virus, the Zika does not usually cause blood dyscrasia. $^{5-8} \mathrm{ZIKV}$ is transmitted through the bite of an infected Aedes aegypti mosquito, which is also a vector of Dengue virus and is endemic to the regions affected. ${ }^{2-8,19}$ Transmission through saliva and/or semen is still controversial, although the presence of live ZIKV has been detected in these secretions. ${ }^{6-8}$ The virus has also been detected in urine. The diagnosis of the virus is usually done clinically. Blood tests are not always available, are costly and take 2 to 7 days to confirm the diagnosis. Enzyme-linked immunosorbent assay (ELISA)-based serological tests can be used for the diagnosis of ZIKV. The test detects the presence of antibodies against ZIKV and, therefore, at the beginning of the symptoms, the test is negative. It should be requested five days after the first signs appear. Real time polymerase chain reaction (RT-PCR) is a method of DNA and RNA amplification that does not use living organisms and can detect ZIKV as symptoms occur. ${ }^{6,9-11}$ ZIKV can be detected in samples of semen or saliva using PCR, but these virus identification kits are not widely available in all countries. The clinical picture triggered by ZIKV resembles a flu-like condition, but chronic complications are more important. Guillain-Barré syndrome (GBS) is a neurological complication that can be fatal, with progressive paralysis of the muscles of the body. In microcephaly, which is brain malformation due to infec-

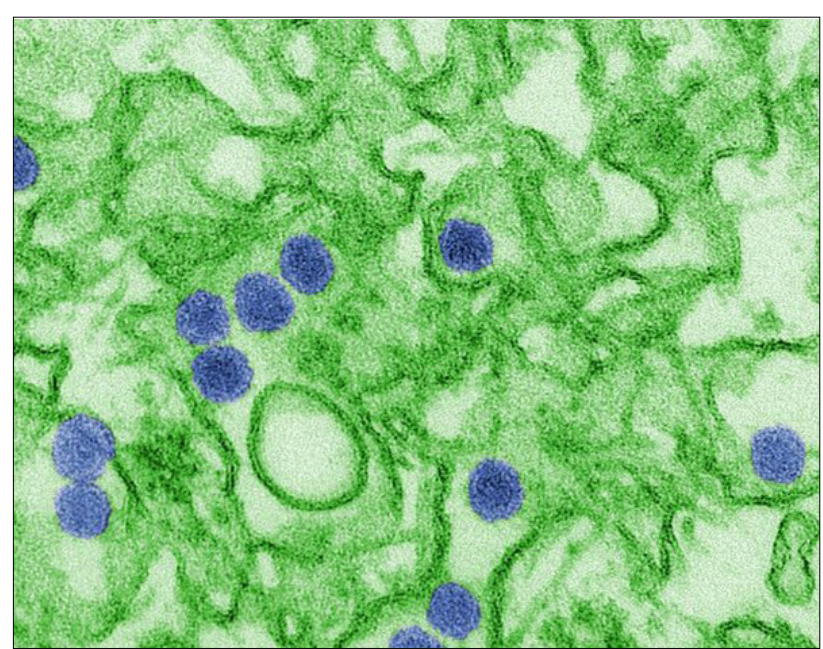

FIGURE 2 Electron micrograph transmission image digitally colored shows Zika virus in blue. (Photo by CDC/Cynthia Goldsmith). $218 \times 164 \mathrm{~mm}(72 \times 72 \mathrm{DPI})$

tion with the virus, the cephalic perimeter is smaller than usual, leading to permanent neurologic loss. It occurs in fetuses of mothers who were infected with ZIKV. ${ }^{2}$ Treatment is usually supportive and depends on the severity of symptoms. The patient usually remains in the hospital for 24-48 hours, under observation with analgesic and antipyretic drugs only. Despite the production of antibodies against ZIKV and Dengue virus, it is not known whether this is lasting immunity or not. ${ }^{9-11,19}$ In cases like GBS or microcephaly, the patients will need hospitalization and continuous care.

\section{Schistosoma}

Schistosomes are trematode parasites approximately 1 $\mathrm{cm}$ (male) to $1.5 \mathrm{~cm}$ (female) long. Schistosome infection is frequent in developing countries with low socioeconomic conditions. Schistosomes are found as three different species, and are considered endemic in Central and South America (S. mansoni), and in the Middle East and Asia (S. haematobium and S. japonicum). In the Americas, the disease is known as water belly or snail fever. The parasite is found in B. glabrata snails, the intermediate host, in freshwater ecosystems. ${ }^{1,13-15,17}$

In the reproductive cycle, the parasite infects the snail, where self-reproduction takes place. The eggs are then discarded in standing water. At that point, the parasite is eliminated (cercaria stage) in water, where its definitive host (human) is infected. Once in the human body, $S$. mansoni has tropism for mesenteric plexus, veins in the pelvic region. In these areas, the parasite reproduces once again and the eggs reach the entire body through veins 
and lymphatic vessels, especially the liver and the spleen (Figure 3). There are reports of eggs found in the kidneys, bladder, prostate, epididymis and testes, which are usually discovered post mortem. ${ }^{15}$ The infectious process that follows is due to the intense immune reaction against the eggs of Schistosoma. The typical lesion is that of granulomas with spiculated egg in a central position (Figure 1).

The granuloma involves the Schistosoma with mast cells, macrophages, multi-nucleated giant cells (Langhans' cells), eosinophils, lymphocytes and fibroblasts. In the process, there is extensive inflammation and fibrosis, egg deposition, and destruction of organ architecture. ${ }^{17,18}$

\section{Discussion}

This is the case of a Brazilian boy, living in an urban area, which starts with a history of testicular increase, with no apparent cause. The initial clinical report, laboratory tests and imaging methods led to a diagnosis of malignant testicular injury. In cases of testicular lesions with suspicion of testicular cancer, testicular biopsy should not be done, as it can promote the spread of malignant cells and loss of surgical healing potential. In this context, the difficulties related to diagnosis and treatment were properly explained to the patient. After the postoperative diagnosis of schistosomal orchitis, and in the absence of malignant tumor of the testicle, it became clear that the collection of clinical data was incomplete. Contact with still waters and whether it was infested with the intermediate host $S$. mansoni was not investigated. Contact with stagnant water 60 days before the onset of symptoms was later confirmed by the patient. We did not inquire about hospitalization for treatment of ZIKV infection, despite the existence of a positive RT-PCR.

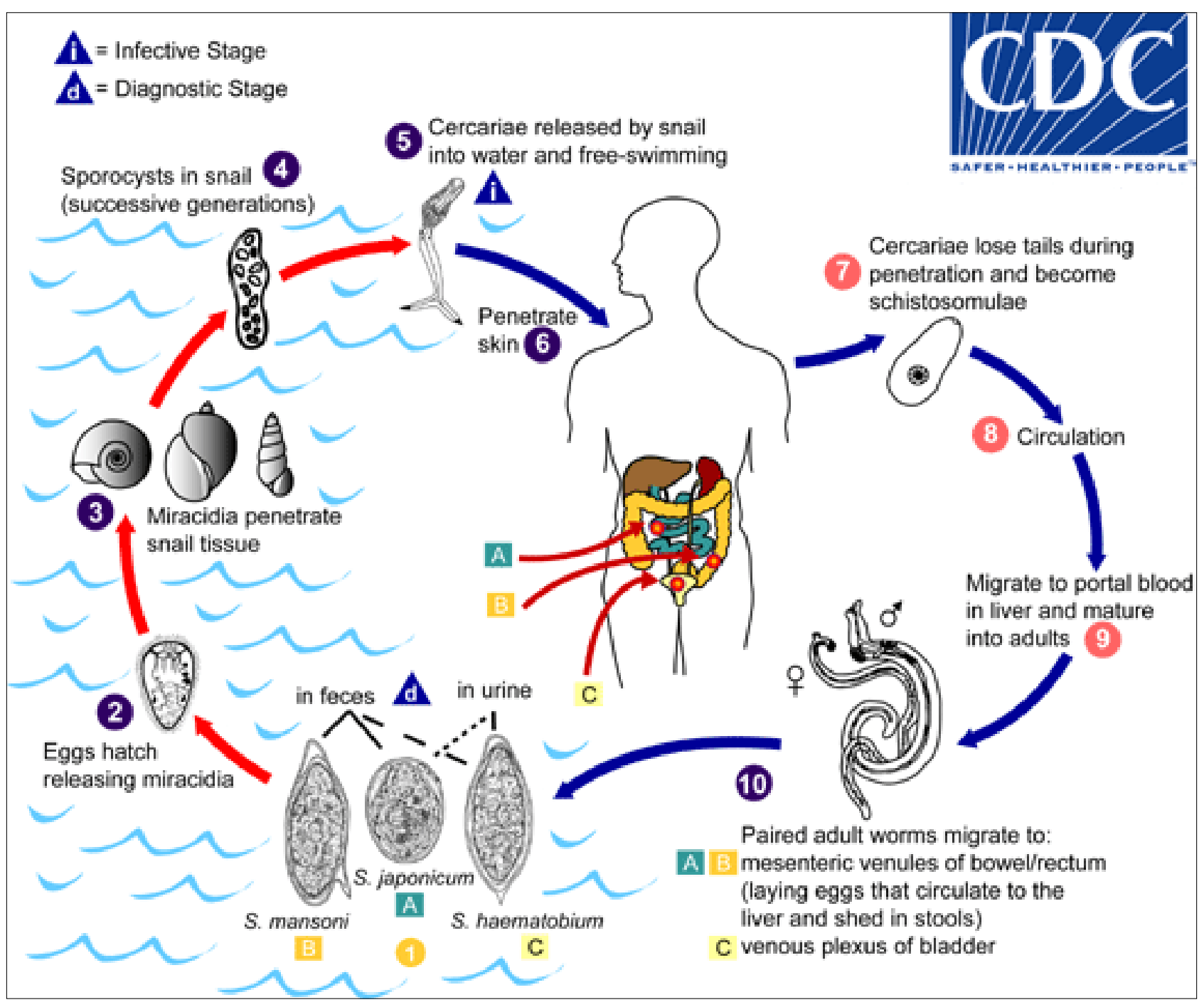

FIGURE 3 Lifecycle of Schistosoma. (From https://www.cdc.gov/parasites/schistosomiasis/biology.html) 
We cannot say if the first infection was that of Schistosoma or Zika. However, literature shows that ZIKV can remain viable in the testicle due to the natural barrier that prevents the formation of testicular antibodies for up to 6 months. ${ }^{14-19}$ Schistosome can remain alive in a definitive host for up to 20 years. ${ }^{18}$ However, with Schistosoma infection and the intense inflammation with granuloma formed around the eggs, this protective barrier to ZIKV was lost, which leads us to believe that the virus was "attacked" by the host's natural defense cells. Unfortunately, we were not able to identify the presence of the virus in the surgical piece due to lack of resources at that time. The literature reports the identification of ZIKV in secretions such as saliva, semen and urine. . $^{3-5,7,8,10,19}$ Test kits for these diagnoses are not always available, but lack of identification does not mean necessarily that the microorganism is not present. Examinations can yield false positives due to a window period. ${ }^{10-12,19}$ The patient was told to use condoms for a period of 6 months, in accordance with the guidelines of health agencies such as the CDC, WHO and Anvisa. ${ }^{3,6,8,10,11,19}$

\section{Conclusion}

Concurrent infection with the two agents may or may not have been a coincidence. We emphasize that all inhabitants of risky areas, as well as people traveling to these places, can be infected with ZIKV and Schistosoma. As the risky areas are endemic for the vectors Aedes aegypt (ZIKV) and Biomphalaria glabrata (Schistosoma), the risk of contracting the two diseases concomitantly is reasonable. The potential complications of two concomitant parasitic infections should determine the efforts to be made by all in order to decrease the prevalence of these diseases. Ultimately, it all comes down to education, basic sanitation and personal hygiene.

\section{Resumo}

Infecção testicular associada com Zika vírus e Schistosoma mansoni em jovem brasileiro

A identificação de massa escrotal sem relato de dor ou trauma deve ser investigada a fim de afastar a possibilidade de câncer escrotal. O artigo reporta o caso de um jovem brasileiro que apresentou massa escrotal com essas características. Ressonância nuclear magnética (RNM) e ultrassonografia (US) indicaram grande possibilidade de câncer. Os marcadores tumorais sanguíneos estavam normais, e a biópsia não poderia ser realizada. O resultado anatomopatológico diagnosticou extensa fibrose esquistossomótica, associada a quadro clínico e sorológico de Zika vírus concomitantemente. Em regiões endêmicas, pacientes com alterações escrotais devem ser pesquisados a fim de evitar cirurgias desnecessárias.

Palavras-chave: vírus Zika, Schistosoma mansoni, testículo, orquiepididimitis.

\section{ACKNOWLEDGMENTS}

We thank Cynthia Goldsmith, CDC/USA, for the ZIKV microphotography. Also, the US CDC for allowing the use of ZIKV and Schistosome lifecycle figures, and F.G., the patient, who allowed us to write this manuscript.

\section{References}

1. Nussenzweig RS. Parasitic disease as a cause of immunosuppression. New Engl J Med. 1982; 306(7):423-4

2. Oehler E, Watrin L, Larre P, Leparc-Goffart I, Lastere S, Valour F, et al. Zika virus infection complicated by Guillain-Barré syndrome--case report, French Polynesia, December 2013. Euro Surveill. 2014; 19(9).pii:20720.

3. Musso D, Roche C, Robin E, Nhan T, Teissier A, Cao-Lormeau VM. Potential sexual transmission of Zika virus. Emerg Infect Dis. 2015; 21(2):359-61.

4. Gourinat AC, O'Connor O, Calvez E, Goarant C, Dupont-Rouzeyrol M. Detection of Zika virus in urine. Emerg Infect Dis. 2015; 21(1):84-6.

5. Oliveira Melo AS, Malinger G, Ximenes R, Szejnfeld PO, Alves Sampaio S, Bispo de Filippis AM. Zika virus intrauterine infection causes fetal brain abnormality and microcephaly: tip of the iceberg? Ultrasound Obstet Gynecol. 2016; 47(1):6-7.

6. Oster AM, Brooks JT, Stryker JE, Kachur RE, Mead P, Pesik NT, et al. Interim guidelines for prevention of sexual transmission of Zika virus - United States, 2016. MMWR Morb Mortal Wkly Rep. 2016; 65(5):120-1.

7. Musso D, Roche C, Nhan TX, Robin E, Teissier A, Cao-Lormeau VM Detection of Zika virus in saliva. J Clin Virol. 2015; 68:53-5.

8. Atkinson B, Hearn P, Afrough B, Lumley S, Carter D, Aarons EJ, et al. Detection of Zika virus in semen. Emerg Infect Dis. 2016; 22(5):940.

9. Hamel R, Dejarnac O, Wichit S, Ekchariyawat P, Neyret A, Luplertlop N, et al. Biology of Zika virus infection in human skin cells. J Virol. 2015; 89(17):8880-96.

10. Mansuy JM, Dutertre M, Mengelle C, Fourcade C, Marchou B, Delobel P, et al. Zika virus: high infectious viral load in semen, a new sexually transmitted pathogen? Lancet Infect Dis. 2016; 16(4):405

11. Hills SL, Russell K, Hennessey M, Williams C, Oster AM, Fischer M, et al. Transmission of Zika virus through sexual contact with travelers to areas of ongoing transmission-continental United States, 2016. MMWR Morb Mortal Wkly Rep. 2016; 65(8):215-6.

12. Oster AM, Russell K, Stryker JE, Friedman A, Kachur RE, Petersen EE, et al. Update: Interim guidelines for prevention of sexual transmission of Zika virusUnited States, 2016. MMWR Morb Mortal Wkly Rep. 2016; 65(12):323-5.

13. Katz N, Almeida, K. Esquistossomose, xistosa, barriga d'água. Ciênc Cultura. 2006; 55(1):38-43.

14. De Silva S, Walsh J, Rown M. Symptomatic Schistosoma mansoni infection as an immune restoration phenomenon in a patient receiving antiretroviral therapy. Clin Infect Dis. 2006; 42(2):303-4.

15. Arban V. Lesions caused by Schistosoma mansoni in the genitourinary tract of men. Am J Clin Pathol. 1956; 26(9):1010-21.

16. Rambau PF, Chandika A, Chalya PL Jackson K. Scrotal swelling and testicular atrophy due to schistosomiasis in a 9-year-old boy: a case report. Case Rep Infect Dis. 2011; 2011:787961.

17. Francolugo-Vélez VA, Zarzosa-Alguiar J. Infección del tracto urinario por Schistosoma haematobioum. Un caso en Cuernavaca, Morelos. México. Rev Mex Urol. 2010; 70(3):187-92

18. Iglesias JD. Aspectos médicos das parasitoses humanas. São Paulo: Guanabara Koogan; 1997. p. 186-210

19. Lyle RD, Peterson LR, Jamerson DJ, Powers AM, Honein MA. Zika virus. N Engl J Med. 2016; 374(16):1552-63. 